\title{
Pesticides Ecotoxicological Risk Assessment for Surface Waters in the Cotton Growing Area Around the Bala's Hippopotamus Pond Biosphere Using PIRI Method
}

\author{
Bazoma Bayili \\ Institut de Recherche en Sciences de la Santé, Direction Régional de l'Ouest \\ (IRSS/DRO), Bobo-Dioulasso, Burkina Faso \\ Université Nazi Boni (UNB), Bobo Dioulasso, Burkina Faso

\section{Richard Ouedraogo}

Institut de l'Environnement et de Recherches Agricoles, Direction Régionale de Recherche Environnementale et Agricole de l'Ouest,

(INERA/DRREA-O), Bobo Dioulasso, Burkina Faso

Unité Mixte de Recherche Internationale - Environnement, Santé et Société (UMI 3189, ESS) CNRS/UCAD/UGB/USTTB/CNRST

\section{Hassane Sidibe}

Ministère de l'Environnement, de l'Economie Verte et du Changement Climatique (MEEVCC)

\section{Sylvain Ilboudo}

Unité Mixte de Recherche Internationale - Environnement, Santé et Société (UMI 3189, ESS) CNRS/UCAD/UGB/USTTB/CNRST

Institut de Recherche en Sciences de la Santé (IRSS),

Ouagadougou, Burkina Faso

Georges Anicet Ouedraogo

Université Nazi Boni (UNB), Bobo Dioulasso, Burkina Faso

Doi:10.19044/esj.2021.v17n14p167

Submitted: 05 December 2020

Accepted: 31 March 2021

Published: 30 April 2021
Copyright 2021 Author(s)

Under Creative Commons BY-NC-ND

4.0 OPEN ACCESS

Cite As:

Bayili B., Ouedraogo R., Sidibe H., Ilboudo S. \& Ouedraogo G.A. (2021). Pesticides Ecotoxicological Risk Assessment for Surface Waters in the Cotton Growing Area Around the Bala's Hippopotamus Pond Biosphere Using PIRI Method. European Scientific Journal, ESJ, 17(14), 167. https://doi.org/10.19044/esj.2021.v17n14p167

\section{Abstract}

Pesticides residues are frequently found in the environment far from the original point of their application. Besides the desired effects of pest 
control, non-target organisms, soil and water are contaminated by the pesticides. This paper presents results on the impact of these xenobiotics used in cotton cultivation on River "Wolo" environment in Burkina Faso by using the Pesticide Impact Rating Index (PIRI) software package. The assessment was based on the assumption of three scenarios taking into account the organic matter content of the soil and the presence of a buffer zone. Pesticides properties and use data, and data on the physical environment, were also used. Considering the worst case (scenario 2), diuron, haloxyfop-R-methyl, glyphosate and nicosulfuron were the most mobile. Diuron was classified as the most toxic pesticide to Scenedesmus quadricauda. Toxicity to Daphnia magna was extremely high with chlorpyrifos ethyl, very high with betacyfluthrin, deltamethrin, lamda-cyalothrin and high with flubendiamide. For Oncorhynchus mykiss, it was beta-cyfluthrin, deltamethrin and lamdacyhalothrin that caused a very high risk and chlorpyrifos ethyl and indoxacarb a high risk. For all pesticides, the risks are reduced overall depending on the width of the buffer zone and the organic matter content of the soil. The use of a pesticide in a given location must take into account its ecotoxicological impact on the surrounding ecosystem. Tools such as PIRI, could be used for the selection of pesticides to be used. Also, environmental parameters such as buffer zone and organic matter content should be used by farmers to limit the mobility of pesticides to water.

Keywords: Risks, pesticides, ecotoxicity, PIRI, Bala

\section{Introduction}

Conventional cotton production involves the massive use of different types of pesticides to control undesirable plants (herbicides), fungi (fungicides) and insect pests (insecticides) (Bayili et al., 2019, Gouda et al., 2018). The use of pesticides in cotton cultivation reduces crop losses (Miranda et al., 2013), which can be more than 50\% (Traoré, 2008; Moussa, 2003; Silvie and Gozé, (1991) in the absence of phytosanitary treatments.

Although very useful, the abundant and abusive use of pesticides can lead to risks to human health (Shokrzadeh and Saravi, 2011; Fournier and Bonderef, 1983) and the environment (Calvet et al., 2005; Padovani et al., 2004). The risks to the environment concern not only contamination of air, soil and water but also toxicity to the non-target organisms. This toxicity is linked to contaminants that reach the living environment of living organisms through fairly complex processes. For pesticides, the process of water contamination seen by Morissette and Martel (2014) highlights a phenomenon of diffuse origin (erosion, runoff, leaching, preferential flow and drift) due to pesticide applications. Pesticides such as herbicides are applied directly to the soil, which increases the risk of leaching or erosion of pesticides into 
groundwater or surface water (Taghavi, 2010; Aubertot et al., 2005). Under conditions of poor practice, poor management of rinse water could be associated, which can also contribute to contamination (Morissette and Martel, 2014). According to Mamy et al (2008), this contamination is influenced by:

- agro-pedoclimatic components such as soil texture and organic matter, rainfall, topography;

- technological components such as tillage, rotations, doses and frequency of pesticide applications; and

- the physicochemical properties of the pesticides used.

Knowledge of the environmental impact of pesticide use is based on the use of several methods. For example, direct and in situ measurements provide accurate data, but are generally expensive and difficult to implement and multiply (Bockstaller and Girardin, 2003; Mamy et al., 2008). Risk assessment methods, in this case indicators and models, help farmers and decision-makers to compare the environmental impact of different pesticides and to design effective control practices with minimal environmental impacts (Samuel et al., 2012; Muhammetoglu et al., 2010; Aravinna et al., 2005). One such method is the Pesticide Impact Rating Index (PIRI) which was developed by CSIRO (Kookana et al., 2005) to assess the potential impact of pesticides on water quality. It has already been used in Burkina Faso to assess the risk of surface and groundwater contamination by pesticides used in industrial sugar cane cultivation (Ouedraogo et al., 2012; Toe et al., 2012). However, a similar study has not been carried out on cotton crops to estimate the ecotoxicological potential of pesticides on specific aquatic ecosystems in adjacent environments. In cotton cultivation, the risks would be increased due to poor pesticide use practices (Bayili et al., 2019; Son et al., 2017; Tarnagda et al., 2017). The use of banned pesticides, overdosing, failure to maintain safe distances between fields and water points, lack of buffer zones, inappropriate mixing of pesticides, etc. are common practices among farmers.

The aim of this study was to assess the ecotoxicological impact of pesticides used for cotton growing on the aquatic systems of the river "Wolo" around the Bala's hippopotamus pond biosphere by using PIRI. The ecotoxicological potential was estimated for three aquatic organisms, the main links in the surface water trophic chain.

\section{Methodology}

\section{Description of the study site}

The study took place around the Bala's hippopotamus pond biosphere reserve, about $50 \mathrm{~km}$ north of the city of Bobo-Dioulasso in Burkina Faso (figure 1). This locality is part of the western zone of the "Société Burkinabé des Fibres et Textiles (SOFITEX)", the country's main conventional cotton 
producer. This area is characterised by a Sudanian climate and an average rainfall of 986.7 measured during the study period. The minimum, maximum and average temperatures were $25.88^{\circ} \mathrm{C}, 28.01^{\circ} \mathrm{C}$ and $26.916^{\circ} \mathrm{C}$ respectively. In general, the soils are mainly tropical ferruginous soils with medium and shallow leaching, staining and indurated concretions, and hydromorphic soils with little humus and a pseudogley surface (BUNASOL, 2002). The hydrographic network of the reserve is made up of the Mouhoun River to the northwest and its tributary the "Wolo" to the southwest, which collects runoff from the cotton growing area towards the pond (Belem, 2008). The waters of the "Wolo" are the passive ones likely to be contaminated mainly by runoff, given the position and distance of this river from the cotton fields.

For the assessment, we monitored farming practices in four cotton fields adjacent to the river, from July to October during the 2018-2019 agricultural season. All the pesticide formulations used by these producers have been identified and characterized (table I). Site and stream characteristic data were collected (table II). The average soil organic matter content (1.4\%), the erosion rate $(0.4 \mathrm{t} / \mathrm{ha} / \mathrm{year})$ and the soil type were obtained from 'Bureau National des Sols du Burkina Faso' (BUNASOL) databases (BUNASOL, 2002). 


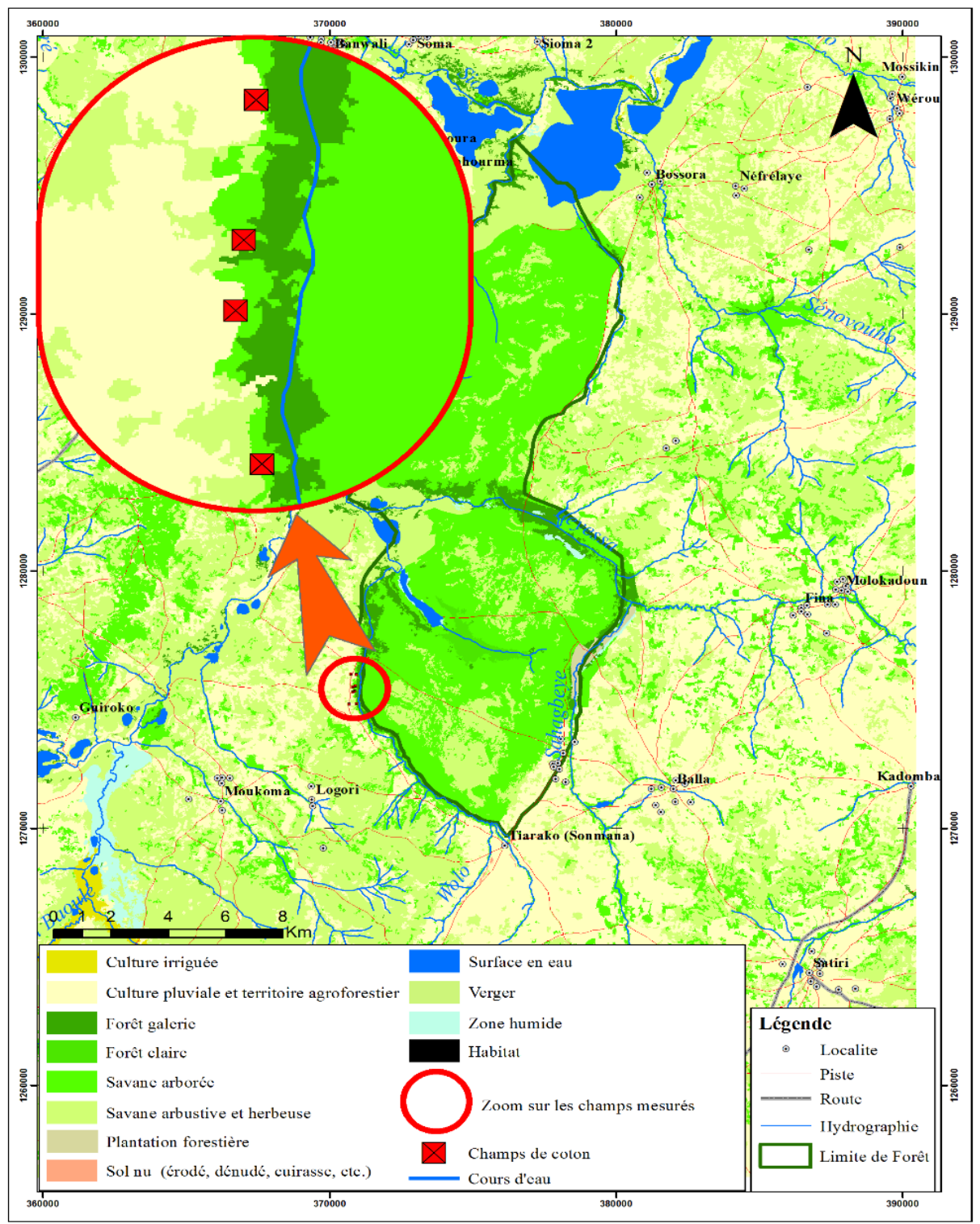

Figure 1: Location map of the study site, realized by Kinda (2019)

\section{Pesticide Impact Rating Index (PIRI)}

The Pesticide Impact Rating Index (PIRI) model was developed in Australia by the Commonwealth Scientific and Industrial Research Organization (CSIRO) to assess the potential impact of pesticides on water quality. It predicts the potential for chemical pesticides to move away from their place of application to pollute adjacent watercourses (CSIRO, 2001). The mobility of the pesticide and its effect on organisms is calculated by taking into account its toxicity, chemical properties, application rate and frequency. 
Local soil and climate conditions are also taken into account (Kookana et $a l ., 2005)$. The main transport routes for pesticides to surface water bodies are runoff, soil colloid erosion and spray drift. The pesticide concentration in the receiving water (CSW) is calculated from the pesticide load moving into the surface water adjacent to the treated area according to the following formula:

$\mathbf{C S W}=\mathbf{L} \times \mathbf{T} \times \mathbf{W I} / \mathbf{H}$ : with: $\mathbf{C S W}\left(\right.$ in $\left.\mathrm{kg} / \mathrm{m}^{3}\right)$ the predicted concentration; $\mathbf{H}(\mathrm{m})$ the depth of the surface water body; $\mathbf{L}$, the load of the pesticide applied to the soil; $\mathbf{T}$, the overall surface transport coefficient for each pesticide; and WI, the water index defined as an approximate ratio of the length of the river bank adjacent to the perimeter of the area to be treated.

Impact assessment based on toxicity for an organism is made by considering a series of aquatic organisms represented by different trophic levels. These are the LC50 for rainbow trout used as a measure of toxicity to fish, the LC50 for Daphnia sp. and the EC50 for algae (Kookana et correll, 2008; Kookana et $a l, 2005)$. The negative impact of the amount of pesticide moving away from the spray site is governed by the concentration of the pesticide in the receiving environment $(\mathrm{Cws})$ relative to the concentration that is toxic to the exposed organism. The risk index for surface water is calculated by the model from the predicted concentration (CSW) and the toxicity value (EC50 or LC50).

\section{Risk index for surface water $=$ Csw / EC50 or LC50}

Each pesticide is classified by PIRI in one of the following risk categories: "very low", "low", "moderate", "high", "very high", and "extremely high" according to its ecotoxicological potential, more than another pesticide that is also subject to the same site conditions (Kookana and Correll, 2008).

For the present study, the reference species "daphnia magna" for crustaceans, "Oncorhynchus mykiss" for fish and "Scenedesmus quadricauda" for algae were chosen according to their ecological importance and the availability of ecotoxicological data. For the active ingredients (table I), all KOC, DT50, crustacean LC50, and most fish LC50 and algae EC50 values have been provided by the Pesticide Properties Database (Footprint PPBD, 2020). 
Table I: Technological, physico-chemical and ecotoxicological characteristics of pesticides

\begin{tabular}{|c|c|c|c|c|c|c|c|c|}
\hline \multirow{2}{*}{ Pesticide formulation } & \multirow{2}{*}{$\begin{array}{c}\text { Active ingredient } \\
\text { (a.i.) }\end{array}$} & \multirow{2}{*}{$\begin{array}{c}\text { Concentration } \\
\text { a.i. (g/L or } \\
\text { g/kg) }\end{array}$} & \multirow{2}{*}{$\begin{array}{c}\text { Application } \\
\text { rate } \\
\text { (kg or } \mathrm{L} / \mathrm{ha})\end{array}$} & \multirow{2}{*}{$\begin{array}{c}\text { Koc } \\
(\mathrm{mL} / \mathrm{g})\end{array}$} & \multicolumn{2}{|c|}{$\mathrm{LC50}(\mathrm{mg} / \mathrm{L})$} & \multirow{2}{*}{$\begin{array}{c}\mathbf{E C 5 0}(\mathbf{m g} / \mathbf{L}) \\
\text { Scenedesmus } \\
\text { quadricauda }\end{array}$} & \multirow{2}{*}{$\begin{array}{l}\text { DT50 } \\
\text { (days) }\end{array}$} \\
\hline & & & & & $\begin{array}{c}\text { Oncorhynchus } \\
\text { mykiss) }\end{array}$ & daphnia magna & & \\
\hline \multirow{2}{*}{ ACERO 84 EC $^{*}$} & $\begin{array}{c}\text { Isoclast } \\
\text { /sulfoxaflor }\end{array}$ & 48 & 0.5 & 40.8 & $>101$ & $>399$ & $>101$ & 2.2 \\
\hline & $\begin{array}{l}\text { Lambda- } \\
\text { cyhalothrin }\end{array}$ & 36 & 0.5 & 283707 & 0.00021 & 0.00036 & $>0.3$ & 175 \\
\hline $\begin{array}{l}\text { ADWUMA WURA } 480 \\
\text { SL }^{* *}\end{array}$ & Glyphosate & 480 & 2 & 1424 & 38.0 & 40 & $>72.9$ & 15.0 \\
\hline AVAUNT 150 EC $^{*}$ & Indoxacarb & 150 & 0.17 & 17.6 & $>0.17$ & 0.17 & $>108^{1}$ & 113.2 \\
\hline DIURALM $80 \mathrm{WG}^{* * *}$ & Diuron & 800 & 1 & 813 & $4.9^{2}$ & 5.7 & 0.0027 & 75.5 \\
\hline GALLANT SUPER $^{* *}$ & $\begin{array}{l}\text { Haloxyfop-R- } \\
\text { methyl }\end{array}$ & 104 & 0.9 & 66 & $0.46^{3}$ & 12.3 & $>94.9^{3}$ & 0.5 \\
\hline GLYPHADER $360 \mathrm{SL}^{* *}$ & Glyphosate & 360 & 2 & 1424 & 38.0 & 40 & 4.4 & 15.0 \\
\hline $\begin{array}{l}\text { GRAMOSHARP } \\
\text { SUPER }^{* *}\end{array}$ & Paraquat dichloride & 200 & 0.5 & 1000000 & 19 & 4.4 & $0.04^{4}$ & 365 \\
\hline INDOXAN* $^{*}$ & Indoxacarb & 50 & 0.5 & 17.6 & $>0.17$ & 0.17 & 0.079 & 113.2 \\
\hline POWER 80 WG $^{* *}$ & Diuron & 800 & 4 & 813 & 4.9 & 5.7 & 0.0027 & 75.5 \\
\hline \multirow{2}{*}{$\begin{array}{l}\text { PYRINEX QUICK } \\
\text { 424EC }^{*}\end{array}$} & Deltametrin & 24 & \multirow{2}{*}{0.5} & 10240000 & 0.00026 & 0.00056 & $2.560^{6}$ & 13 \\
\hline & Chlorpyrifos ethyl & 400 & & 5509 & 0.025 & 0.00010 & $0.660^{7}$ & 386 \\
\hline \multirow[t]{2}{*}{ THUNDER $*$} & Imidacloprid & 100 & \multirow[t]{2}{*}{0.2} & 255 & $>83$ & 85 & $>10^{8}$ & 191 \\
\hline & Beta-cyfluthrin & 45 & & 64300 & 0.000068 & 0.00029 & $>0.01^{9}$ & 13 \\
\hline \multirow{2}{*}{ TIHAN 175 O-TEQ } & Spirotetramat & 75 & \multirow[b]{2}{*}{0.22} & 289 & $2.54^{10}$ & $>42.7$ & $0.36^{11}$ & 0.19 \\
\hline & Flubendiamide & 100 & & 2197 & 0.06 & 0.06 & $>0.069$ & 500 \\
\hline
\end{tabular}

*insecticide ; **herbicide ; ${ }^{1} \mathrm{ECHA}, 2020 ;{ }^{2} \mathrm{Fojut}$ et al, $2011 ;{ }^{3} \mathrm{FAO}, 2012 ;{ }^{4}$ Sáenz et al., $1993 ;{ }^{5} \mathrm{PubChem}, 2020 \mathrm{a} ;{ }^{6} \mathrm{PubChem}, 2020 \mathrm{~b} ;{ }^{7} \mathrm{NRA}$, $2020 ;{ }^{8} \mathrm{CCME}, 2007 ;{ }^{9} \mathrm{FAO}, 2016 ;{ }^{10}$ Agbohessi et al., $2013 ;{ }^{11}$ ANLA, 2018. 


\section{Scenarios}

- Scenario 1 (actual case observed) where the soil organic matter content is $1.4 \%$, with a buffer zone;

- Scenario 2 where the soil organic matter content was maintained at $1.4 \%$ and a $5 \mathrm{~m}$ non-vegetated zone was assumed;

- Scenario 3 includes a soil organic matter content of $2 \%$, a distance between the field and the water course of $100 \mathrm{~m}$ (Agence de l'Eau du Nakanbé (AEN), 2015) and a $5 \mathrm{~m}$ grassed buffer zone.

Table II: Characteristic data of the site and the river "Wolo".

\begin{tabular}{lc}
\hline Measured parameters & Values \\
\hline Distance from the edge of the field to the water surface $(\mathbf{m})$ & 75.25 \\
\hline Average river diameter $(\mathbf{m})$ & 5.625 \\
\hline Average depth of river $(\mathbf{m})$ & 1.625 \\
\hline Erosion rate $(\mathbf{t} / \mathbf{h a} / \mathbf{y e a r})$ & 0.4 \\
\hline Slope & 1.89 \\
\hline Type of soil & Clay-silt \\
\hline Organic matter content $(\boldsymbol{\%})$ & 1.4 \\
\hline Total rainfall during the period $($ June to October) $(\mathbf{m m})$ & 986.7 \\
\hline Average minimum temperature during the period $\left({ }^{\circ} \mathbf{C}\right)$ & 21.82 \\
\hline Average maximum temperature during the period $\left({ }^{\circ} \mathbf{C}\right)$ & 33.05 \\
\hline $\begin{array}{l}\text { Minimum number of days between the application of } \\
\text { pesticides and the first rainfall }\end{array}$ & 2 \\
\hline
\end{tabular}

\section{Results and discussion}

\section{Potential for mobility}

Mobility (table III) is high for Diuron, Haloxyfop-R-methyl, glyphosate and nicosulfuron in scenario 2. Adsorption coefficients (Koc) indicate that glyphosate and diuron are slightly mobile while nicosulfuron and Haloxyfop-R-methyl are mobile. Their mobility is very low in Scenario 1, where the width of the buffer zone $(75.25 \mathrm{~m})$ was the determining factor for this decrease. Thanks to its phytoremediation capacity, the vegetated strip of the buffer zone has a great influence on reducing the risk of water pollution by chemical pesticides (Trainer and Volker, 2008). This parameter acts as a brake on erosion, which is one of the factors contributing to the pollution of surface waters by pesticides. In scenario 3, where only diuron has a high mobility, the overall risk reduction is influenced by the increase in soil organic matter content (2\%). Organic matter increases the activity of microorganisms that have the power to degrade organic pesticides in general. It adsorbs pesticides, increases their residence time in soils and promotes their degradation by microorganisms (Savadogo et al., 2006). It also accelerates the degradation of pesticides in the soil (Savadogo et al., 2008). Since microorganisms are the former agents for the degradation of organic contaminants in soil, the 
application of organic matter, which increases microbial density and also provides nutrients and readily degradable organic matter can be considered useful to accelerate the contaminant degradation (Takeshita et al., 2019; Gómez et al., 2014; Masciandaro et al., 2013). Moreover, the organic matter addition, by means of the increase of cation exchange capacity, soil porosity and water-holding capacity, enhances the soil health and provides a medium satisfactory for microorganism activity. The buffer zone and organic matter could offer solutions within the framework of a risk management plan for pesticide mobility (Calvet et $a l .$, 2005; Ouedraogo et $a l ., 2012$ ).

Table III: Classification of pesticide mobility

\begin{tabular}{llll}
\hline Pesticide & Scenario 1 & Scenario 2 & Scenario 3 \\
\hline Diuron & Very low & High & High \\
\hline Haloxyfop-R-methyl & Very low & High & Medium \\
\hline Glyphosate & Very low & High & Medium \\
\hline Nicosulfuron & Very low & High & Medium \\
\hline Sulfoxaflor & Very low & Medium & Medium \\
\hline Imidacloprid & Very low & Medium & Medium \\
\hline Chlorpyrifos ethyl & Very low & Medium & Medium \\
\hline Paraquat dichloride & Very low & Medium & Low \\
\hline Flubendiamide & Very low & Low & Low \\
\hline Indoxacarb & Very low & Low & Very low \\
\hline Lamda-cyhalothrin & Very low & Very low & Very low \\
\hline Deltamethrin & Very low & Very low & Very low \\
\hline Beta-cyfluthrin & Very low & Very low & Very low \\
\hline Spirotetramat & Very low & Very low & Very low \\
\hline
\end{tabular}

\section{Impact on Scenedesmus quadricauda}

The classification of the impact of pesticides on algae is given in table IV. Diuron causes an extremely high risk in scenarios 2 and 3 and a very high risk in scenario 1 . The other pesticides induce a toxicity ranging from very low to medium according to the different scenarios. The high estimated mobility and intrinsic toxicity of diuron towards algae are at the origin of the risk of this herbicide. This level of toxicity of this pesticide towards algae could threaten the health and productivity of the aquatic ecosystem, given the importance of phytoplankton in the trophic chain. The data from Scenario 1 show that risk reduction was influenced by the width of the buffer zone, when the data from this scenario are compared overall with those from the other scenarios. Indeed, except for diuron, the risks are low to very low for all pesticides. 
Table IV: Classification of pesticide toxicity to Scenedesmus quadricauda

\begin{tabular}{llll}
\hline Pesticide & Scenario 1 & Scenario 2 & Scenario 3 \\
\hline Beta-cyfluthrin & Very low & Medium & Medium \\
\hline Chlorpyrifos ethyl & Very low & Medium & Medium \\
\hline Deltamethrin & Very low & Very low & Very low \\
\hline Diuron & Very high & Exc. high & Exc. high \\
\hline Flubendiamide & Very low & Medium & Medium \\
\hline Glyphosate & Very low & Very low & Very low \\
\hline Haloxyfop-R-methyl & Very low & Very low & Very low \\
\hline Imidacloprid & Very low & Low & Low \\
\hline Indoxacarb & Very low & Very low & Very low \\
\hline Lamda-cyhalothrin & Very low & Very low & Very low \\
\hline Nicosulfuron & Very low & Low & Low \\
\hline Paraquat dichloride & Low & Medium & Medium \\
\hline Spirotetramat & Very low & Very low & Very low \\
\hline Sulfoxaflor & Very low & Very low & Very low \\
\hline
\end{tabular}

\section{Impact on Daphnia magna}

Table V presents the results of the impact on Daphnia. In scenario 2, toxicity is extremely high with chlorpyrifos ethyl, very high with betacyfluthrin, deltamethrin, lamda-cyalothrin and high with flubendiamide. All these pesticides are used for their insecticidal effects. The intrinsic toxicity of these pesticides is high towards Daphnia (table I). Despite mitigation measures (in scenarios 1 and 3), the overall toxic impact of these insecticides remains a cause for concern. Indeed, chlorpyriphos-ethyl and lambdacyalothrin have very high and high toxicity respectively in scenario 1 . The use of these potentially toxic pesticides around areas of particular ecological importance, such as the hippopotamus pond biosphere reserve (RBMH), must be strongly controlled in order to preserve the aquatic ecosystem.

Table V: Classification of pesticide toxicity to Daphnia magna.

\begin{tabular}{llll}
\hline Pesticide & Scenario 1 & Scenario 2 & Scenario 3 \\
\hline Beta-cyfluthrin & Medium & Very high & Very high \\
\hline Chlorpyrifos ethyl & Very high & Exc. high & Exc. high \\
\hline Deltamethrin & Medium & Very high & High \\
\hline Diuron & Very low & Medium & Medium \\
\hline Flubendiamide & Very low & High & Medium \\
\hline Glyphosate & Very low & Low & Very low \\
\hline Haloxyfop-R-methyl & Very low & Medium & Low \\
\hline Imidacloprid & Very low & Very low & Very low \\
\hline Indoxacarb & Very low & Low & Low \\
\hline Lamda-cyhalothrin & High & Very high & Very high \\
\hline Nicosulfuron & Very low & Very low & Very low \\
\hline Paraquat dichloride & Very low & Very low & Very low \\
\hline
\end{tabular}




\begin{tabular}{llll}
\hline Spirotetramat & Very low & Very low & Very low \\
\hline Sulfoxaflor & Very low & Very low & Very low \\
\hline
\end{tabular}

\section{Impact on Oncorhynchus mykiss}

The results of the impact assessment on this fish are in table VI. Considering scenario 2, beta-cyfluthrin, deltamethrin and lamda-cyhalothrin cause a very high risk while chlorpyrifos ethyl and indoxacarb cause a high risk. For all these pesticides, the level of risk remains constant in scenario 3. Nevertheless, the general trend is that the level of risk for most other pesticides is decreasing. The risk ranking for these latter pesticides is in the lower order in this scenario 3 , ranging from moderate to very low. The increase in organic matter content and the presence of the buffer zone have caused this decrease. Although the width of the buffer zone in scenario 1 caused a reduction in risk for all pesticides, this is not the case for beta-cyfluthrin and lamda-cyhalothrin for which the risk is high. The classification of these pesticides is greatly influenced by their higher intrinsic toxicity than all other pesticides (table I).

Table VI: Classification of pesticide toxicity to Oncorhynchus mykiss

\begin{tabular}{llll}
\hline Pesticide & Scenario 1 & Scenario 2 & Scenario 3 \\
\hline Beta-cyfluthrine & High & Very high & Very high \\
\hline Chlorpyrifos ethyl & Medium & High & High \\
\hline Deltamethrin & Medium & Very high & Very high \\
\hline Diuron & Very low & Medium & Medium \\
\hline Flubendiamide & Very low & Medium & Medium \\
\hline Glyphosate & Very low & Very low & Very low \\
\hline Haloxyfop-R-methyl & Very low & Low & Very low \\
\hline Imidacloprid & Very low & Very low & Very low \\
\hline Indoxacarb & Very low & High & High \\
\hline Lamda-cyhalothrin & High & Very high & Very high \\
\hline Nicosulfuron & Very low & Very low & Very low \\
\hline Paraquat dichloride & Very low & Very low & Very low \\
\hline Spirotetramat & Very low & Very low & Very low \\
\hline Sulfoxaflor & Very low & Very low & Very low \\
\hline
\end{tabular}

\section{Conclusion}

The level of ecotoxicological risk of pesticides on the waters of the "Wolo" River was estimated using the PIRI model. Considering the worst case (scenario 2), diuron, haloxyfop-R-methyl, glyphosate and nicosulfuron were the most mobile. Diuron was classified as the most toxic pesticide to Scenedesmus quadricauda. Toxicity to Daphnia magna was extremely high with chlorpyrifos ethyl, very high with beta-cyfluthrin, deltamethrin, lamdacyalothrin and high with flubendiamide. In Oncorhynchus mykiss, it was betacyfluthrin, deltamethrin and lamda-cyhalothrin that caused a very high risk and chlorpyrifos ethyl and indoxacarb a high risk. Pesticides have shown a 
differential level of risk depending on their mobility and their toxic properties on organisms. Diuron for algae, chlorpyrifos ethyl and lambda-cyalothrin for Daphnia and beta-cyfluthrin and lamda-cyhalothrin for fish induced at least high toxicity in all scenarios. In general, the association of the buffer zone with the increase in soil organic matter content led to a decrease in the level of risk. The use of a pesticide in a given location must take into account its ecotoxicological impact on the surrounding ecosystem. Tools such as PIRI, could be used for the selection of pesticides to be used. Also, environmental parameters such as buffer zone and organic matter content should be used by farmers to limit the mobility of pesticides to water.

\section{References:}

1. Agbohessi, P., Toko, I., Attakpa, E., and Kestemont, P. (2013). Synthèse des caractéristiques physico-chimiques et effets écotoxicologiques du Tihan 175 O-TEQ utilisé dans la protection phytosanitaire du cotonnier au Bénin. International Journal of Biological and Chemical Sciences, 6(5). DOI: 10.4314/ijbcs.v6i5.34.

2. Agence de l'Eau du Nakanbé (AEN), (2015). Normes et techniques de protection des berges du Nakanbé. Rapport final, Burkina Faso. 53p.

3. Aravinna, A. G. P., Liyanage, J. A. and Mubarak, A. M. (2005). Prediction of pesticide risk on groundwater in the Kalpitiya peninsula using Pesticide Impact Ranking Index (PIRI). Sri Lanka Association for the Advancement of Science, Proceedings of the 61 st Annual Session - 2005 Part 1 - Abstracts.

4. Aubertot, J. N., Barbier, J. M., Carpentier, A., Gril, J.J., Guichard, L., Lucas, P., Savary, S., Savini, I., and Voltz, M. (2005). Pesticides, agriculture et environnement. Réduire l'utilisation des pesticides et limiter leurs impacts environnementaux. Expertise scientifique collective, synthèse du rapport, INRA et Cemagref (France), 64 p.

5. Autoridad Nacional De Licencias Ambientales (ANLA) -Resolución $\mathrm{N}^{\circ}$ 01294, (2018). "Por la cual se emite Dictamen Técnico Ambiental para el producto formulado Speramet $150 \mathrm{OD}$, con base en el ingrediente activo grado técnico Spirotetramat" ("Par lequel un avis technique environnemental est émis pour le produit formulé Speramet 150 OD, basé sur la matière active de qualité technique Spirotetramat"). República de Colombia, Ministerio de Ambiente y Desarrollo Sostenible. Consulter le 23/10/2020 sur l'URL : http://portal.anla.gov.co/sites/default/files/res_1294_10082018_ct_41 44.pdf.

6. Bayili, B., Ouedraogo, R., Ilboudo, S., Pooda, L., Bonkoungou, M., Bationo, J. F., Ouedraogo, J. B., and Ouedraogo, G. A. (2019). Characterization of pesticides and practices of certain actors in the 
cotton zone around the biosphere of the Bala's hippopotamus pond in Burkina Faso. Journal of Experimental Biology and Agricultural Sciences. Journal of Experimental Biology and Agricultural Sciences, 7(6): 554 - 568. DOI: 10.18006/2019.7(6).554.568

7. Belem, M. (2008). Les galeries forestières de la Réserve de la Biosphère de la Mare aux Hippopotames du Burkina Faso : caractéristiques, dynamique et ethnobotanique, Thèse de doctorat d'Etat, Université de Ouagadougou, Burkina Faso. 208p.

8. Bockstaller, C. E., and Girardin, P. (2003). How to validate environmental indicators. Agricultural Systems, 76. 639-653. https://doi.org/10.1016/S0308-521X(02)00053-7

9. Bureau National des Sols du Burkina Faso (BUNASOL), (2002). Etude morpho-pédologique des provinces du Houet et du Tuy. Rapport technique $\mathrm{N}^{\circ} 126,74 \mathrm{p}$.

10. Calvet, R., Barriuso, E., Bénoit, P., Charnay, M. P., and Coquet, Y. (2005). Les pesticides dans le sol : conséquences agronomiques et environnementales. Editions, France Agricole, 637p.

11. Canadian Council of Ministers of the Environment (CCME), (2007). Canadian Water Quality Guidelines: Imidacloprid. Scientific Supporting Document. Canadian Council of Ministers of the Environment, Winnipeg. Assessed, 23/10/2020. Available from URL: https://www.ccme.ca/files/Resources/supporting_scientific_document s/imidacloprid_ssd_1388.pdf.

12. CSIRO., (2001). Pesticide Impact Rating Index. Accessed, 2010, December 11. Available from URL: http:// www.csiro.au/piri.

13. ECHA. Annex Vi - Harmonised Classification and Labelling Indoxacarb and Indoxacarb (Enantiomeric Reaction Mass S: R 75:25). Consulté Le 23/10/2020 Sur L'URL Https://Echa.Europa.Eu/Documents/10162/85def842-B077-974fFcb6-C9450a76031b.

14. Fojut, T. L., Palumbo, A. J., \& Tjeerdema, R. S. (2011). Aquatic Life Water Quality Criteria Derived via the UC Davis Method: III. Diuron. Reviews of Environmental Contamination and Toxicology, 105-141. doi:10.1007/978-1-4614-2260-0_3

15. Food and Agriculture Organization (FAO), (2012). Specifications and Evalutions for Haloxyfop-P-Methyl., assessed, 23/10/2020. Available from URL: http://www.fao.org/fileadmin/templates/agphome/documents/Pests_P esticides/Specs/haloxyfop_2012.pdf.

16. Food and Agriculture Organization (FAO), (2016). FAO Specifications and Evaluations for Plant Protection Products, BetaCyfluthrin. Assessed, 23/10/2020. Available From URL: 
http://www.fao.org/fileadmin/templates/agphome/documents/Pests_P esticides/Specs/beta-cyfluthrin_2017_09_30.pdf.

17. Footprint PPBD. Pesticides properties database. Accessed, 25/08/2020. Available from URL https://sitem.herts.ac.uk/aeru/iupac/atoz.htm.

18. Fournier, E., and Bonderef, J. (1983). Les produits antiparasitaires à usage agricole. Conditions d'utilisation et toxicologie. Tec. Et doc. Lavoisier, Paris, 334 p.

19. Gómez, I., Rodríguez-Morgado, B., Parrado, J., García, C., Hernández, T., Tejada, M. (2014). Behavior of oxyfluorfen in soils amended with different sources of organic matter. Effects on soil biology. J Hazard Mater. 273 :207-14. DOI: 10.1016/j.jhazmat.2014.03.051

20. Gouda, A.I., Toko, I. I., Salami S-D., Richert, M., Scippo, M-L., Kestemont, P., Schiffers, B. (2018). Pratiques phytosanitaires et niveau d'exposition aux pesticides des producteurs de coton du nord du Bénin. Cah. Agric. 27, 65002. DOI : 10.1051/cagri/2018038

21. Kookana, R., and Correll, R. (2008). The Tasmanian River Catchment Water Quality Initiative: Pesticide Impact Rating Index (PIRI) risk indicator for minimizing off-site migration of pesticides. CSIRO Land and Water Science Report series ISSN: 1834-6618.

22. Kookana, R. S., Correll, R. L., and Miller, R. B. (2005). Pesticide impact rating index - a pesticide risk indicator for water quality. Water, Air, and Soil Pollution: Focus (5): 45-65.

23. Mamy, L., Barriuso, E., and Gabrielle, B. (2008). Evaluer les risques environnementaux des pesticides Exemple du désherbage des cultures résistantes ou non au glyphosate. Innovations Agronomiques, INRA, (3), 121-143. https://hal.archives-ouvertes.fr/hal-01192112

24. Masciandaro, G., Macci, C., Peruzzi, E., Ceccanti, B., and Doni, S. (2013). Organic matter-microorganism-plant in soil bioremediation : a synergic approach. Reviews in Environmental Science and Biotechnology, 12, 399-419. https://doi.org/10.1007/s11157-0139313-3

25. Miranda, J. E., Rodrigues, S. M. M., de Almeida, R. P., da Silva, C. A. D., Togola, M., Hema, S. A. O., Somé, N. H., Bonni, G., Adegnika, M. O., Doyam, A. N., Le Diambo, B. (2013). Reconnaissance de ravageurs et ennemies naturels pour les pays C-4 / Brasília, DF, Brésil : Embrapa. 70p. (Échange d'expériences sur le cotonnier). COTON-4.

26. Morissette, S., and Martel S. (2014). Contamination de l'eau par les pesticides dans les secteurs de production de pommes de terre : Problématique et solutions. Fiche d'information. Québec, CANADA.

27. Moussa, A. A., Crétenet, M., Nibouche, S., and Gaborel, C. (2003). Impact d'une attaque précoce de chenilles de la capsule sur le 
rendement en coton graine en fonction de la pluviosité au Nord Cameroun. Savanes africaines : des espaces en mutation, des acteurs face à de nouveaux défis., 2003, Garoua, Cameroun. 6 p. ffhal$00142739 f$

28. Muhammetoglu, A., Durmaz, S., and Uslu, B. (2010). Evaluation of the Environmental Impact of Pesticides by Application of Three Risk Indicators. Scientific Communications. Environmental Forensics, 11 :179-186. https://doi.org/10.1080/15275920903559180.

29. National Registration Authority (NRA) for Agricultural and Veterinary Chemicals. The NRA Review of Chlorpyrifos. Section 6, Environmental Assessment, Australia. Assessed, 23/10/2020. Available from URL: https://apvma.gov.au/sites/default/files/publication/14756chlorpyrifos-irr-environment.pdf.

30. Ouedraogo, R., Pare, S., Toe, A. M., and Guissou, I. P. (2012). Pesticides risk assessment by PIRI for surface water in sugar cane cultivation in Burkina Faso. Journal of Environmental Hydrology, 20(16):1 - 10. http://www.hydroweb.com

31. Padovani, L., Trevisan, M., and Capri, E. (2004). A calculation procedure to assess potential environmental risk of pesticides at the farm level. Ecological Indicators 4 :111-123. DOI : 10.1016/j.ecolind.2004.01.002.

32. PubChem, (2020a). Nicosulfuron. Consulté le 23/10/2020 sur l'URL : https://pubchem.ncbi.nlm.nih.gov/compound/Nicosulfuron.

33. PubChem, (2020b). Deltamethrin. Consulté le 23/10/2020 sur l'URL : https://pubchem.ncbi.nlm.nih.gov/compound/Deltamethrin.

34. Sáenz, M. E., Accorinti, J., Tortorelli, M., and del C. (1993). Toxicity of paraquat to a green alga scenedesmus acutus. Journal of Environmental Science and Health, Part B, 28(2), 193-204. doi:10.1080/03601239309372822

35. Samuel, O., Dion, S., St-Laurent, L., and April, M.-H. (2012). Indicateur de risque des pesticides du Québec - IRPeQ - Santé et environnement [en ligne]. Québec : ministère de l'Agriculture, des Pêcheries et de 1'Alimentation/ministère du Développement durable, de l'Environnement et des Parcs/Institut national de santé publique du Québec, 48 p. consultable sur l'URL : < http://www.mddep.gouv.qc.ca> et < http://www.inspq.qc.ca>.

36. Savadogo, P. W., Lompo, F., Bonzi-Coulibaly, Y. L., Traoré, A. S., and Sedogo P. M., (2008). Influence de la Température et des Apports de Matière Organique sur la Dégradation de l'Endosulfan dans trois types de Sols de la Zone Cotonnière du Burkina Faso. J. Soc. OuestAfr. Chim. $026 ; 79-87$. 
37. Savadogo, P. W., Traoré, O., Topan, M., Tapsoba, K. H., Sedogo, P. M., and Bonzi-Coulibaly L. Y. (2006). Variation de la teneur en résidus de pesticides dans les sols de la zone cotonnière du Burkina Faso. Journal Africain des Sciences de l'Environnement, Numéro 1, 29-39p.

38. Shokrzadeh, M., and Saravi, S. S. S. (2011). Pesticides in agricultural products: analysis, reduction, and prevention. Department of toxicology-pharmacology, faculty of pharmacy, Mazandaran University of Medical Sciences. DOI: 10.13140/2.1.3540.4803

39. Silvie, P., and Gozé E. (1992). Estimation des pertes de production dues aux ravageurs du cotonnier au Tchad. Cot. Fib. Trop., vol. 46, fasc. 1 - 15. Cirad - Agritrop (https://agritrop.cirad.fr/416610/)

40. Son, D., Somda, I., Legreve, A., and Schiffers, B. (2017). Pratiques phytosanitaires des producteurs de tomates du Burkina Faso et risques pour la santé et l'environnement. Cahiers Agricultures $26: 250-255$. DOI : $10.1051 /$ cagri/2017010

41. Taghavi, L., (2010). Dynamique de transfert des pesticides en périodes de crue sur les bassins versants agricoles gascons. Thèse de doctorat en Hydrologie, Hydrochimie, Sol, Environnement, Université de Toulouse, France. 205p + annexes

42. Takeshita, V., Mendes, K.F., Alonso, F.G., and Tornisielo, V.L. (2019). Effect of organic matter on the behavior and control effectiveness of herbicides in soil. Planta Daninha; v37:e019214401. https://doi.org/10.1590/s0100-83582019370100110.

43. Tarnagda, B., Tankoano, A., Tabsoba, F., Sourabie, P. B., Abdoullahi, H.O., Djbrine, A. O., Drabo, K. M., Traore, Y., and Savadogo, A. (2017). Évaluation des pratiques agricoles des légumes feuilles : le cas des utilisations des pesticides et des intrants chimiques sur les sites maraîchers de Ouagadougou, Burkina Faso. Journal of Applied Biosciences 117 : 11658-11668. 10.4314/jab.v117i1.3.

44. Toe, A. M., Ouedraogo, R., and Pare S. (2012). Groundwater risk assessment of pesticides used by sn-sosuco for sugar cane cultivation in Burkina Faso. Journal of Environmental Hydrology 20:1 - 9. http://www.hydroweb.com

45. Trainer, E., and Volker, P. (2008). Assessing runoff water quality following pesticide applications for validation of the PIRI risk assessment tool. Division of Forest Research and Development, Technical Report 02/2008, Forestry Tasmania, Hobart, 13p.

46. Traoré O. (2008). Les succès de la lutte intégrée contre les ravageurs du cotonnier en Afrique de l'Ouest. Communication à la $67^{\text {ème }}$ réunion plénière de l'ICAC. Ouagadougou (Burkina Faso), 16-21 November 2008, pp.11. 